\title{
Brown Ring Patch: A New Disease on Bentgrass Caused by Waitea circinata var. circinata
}

Takeshi Toda, The United Graduate School of Agricultural Science, Gifu University, 1-1Yanagido, Gifu 501-1193, Japan; Tomoyuki Mushika, Laboratory of Plant Disease Science, Faculty of Agriculture, Gifu University, 1-1 Yanagido, Gifu 501-1193, Japan; Toshihiro Hayakawa, Research Institute of Riken Green Co., Ltd., 859-1 Minamidaiheishinden, Fukude, Iwata, Shizuoka 437-1212, Japan; Akemi Tanaka and the late Toshikazu Tani, Institute for Green Science, 3335-2 Showa, Sanuki, Kagawa 769-2304, Japan; and Mitsuro Hyakumachi, Laboratory of Plant Disease Science, Faculty of Agriculture, Gifu University, 1-1 Yanagido, Gifu 501-1193, Japan

\begin{abstract}
Toda, T., Mushika, T., Hayakawa, T., Tanaka, A., Tani, T., and Hyakumachi, M. 2005. Brown ring patch: A new disease on bentgrass caused by Waitea circinata var. circinata. Plant Dis. 89:536-542.

Isolates of an unidentified Rhizoctonia sp. (NP isolates), obtained from creeping bentgrass (Agrostis stolonifera var. palustris) in Japan that exhibited symptoms of a new disease, were compared with isolates of three varieties of Waitea circinata var. oryzae, var. zeae, and var. circinata. NP isolates also were compared with isolates of $R$. oryzae obtained from creeping bentgrass exhibiting white patch-like symptoms (RW isolates). The color and size of sclerotia, color of mycelia, and pigment deposition of NP isolates was similar to that of RW isolates and $W$. circinata var. circinata, but distinctly different from $W$. circinata var. oryzae and W. circinata var. zeae. The optimal temperature for hyphal growth of NP isolates, RW isolates, and W. circinata var. circinata was $28^{\circ} \mathrm{C}$, and for W. circinata var. oryzae and W. circinata var. zeae was $30^{\circ} \mathrm{C}$. Pathogenicity tests on creeping bentgrass showed that the severity of disease caused by NP isolates, RW isolates, and W. circinata var. circinata was greater than with W. circinata var. oryzae, but lower than with $W$. circinata var. zeae. No significant differences in symptom expression were apparent among NP isolates, RW isolates, and W. circinata var. circinata. A phylogenic tree, obtained using the results of random amplified polymorphic DNA-polymerase chain reaction (RAPD-PCR), showed that isolates of W. circinata var. oryzae and W. circinata var. zeae separated into individual clusters, while NP isolates, RW isolates, and W. circinata var. circinata clustered together. The lengths of the rDNA internal transcribed spacer (ITS) region of NP isolates, RW isolates, and W. circinata var. circinata were identical but smaller than those of $W$. circinata var. oryzae and W. circinata var. zeae. Restriction fragment length polymorphism (RFLP) analysis of the rDNA-ITS region, using three enzymes (HapII, HinfI, and MboI), also showed that NP isolates were the same as RW isolates and W. circinata var. circinata, but different from W. circinata var. oryzae and W. circinata var. zeae. Based on these results, the NP isolates causing a new disease on bentgrass are W. circinata var. circinata, and that RW isolates are also $W$. circinata var. circinata but not $R$. oryzae. We propose that the name of the disease on creeping bentgrass caused by $W$. circinata var. circinata is brown ring patch.
\end{abstract}

Additional keywords: Rhizoctonia solani AG 2-2 IIIB

A new disease was found in Japan on creeping bentgrass (Agrostis stolonifera var. palustris Huds.) from spring through autumn in $1994(7,11)$. This disease was found on bentgrass putting greens on golf courses throughout Japan and occurred during rainy periods. Symptoms included circular or irregular small patches of tan to

Corresponding author: M. Hyakumachi

E-mail: hyakumac@cc.gifu-u.ac.jp

Accepted for publication 21 January 2005.

DOI: 10.1094/PD-89-0536

(C) 2005 The American Phytopathological Society yellow-brown color ranging from 10 to 50 $\mathrm{cm}$ in diameter. The symptoms of this disease were found on plant tissues above the soil surface. The affected turf eventually developed brownish rings, but the turf in the center of the rings recovered. In some cases, the turf recovered completely. Isolates of a Rhizoctonia sp. (NP isolates), obtained from plants affected by this new disease, were multinucleate and anastomosed with tester isolates of Rhizoctonia oryzae Ryker \& Gooch and R. zeae Voorhees (7). However, the cultural morphology of NP isolates was different from these species.

Waitea circinata Warcup \& Talbot was classified into three varieties, W. circinata var. circinata, W. circinata var. oryzae, and W. circinata var. zeae, based on differences in the colony morphology of the vegetative state (5). Although the anamorphic name of $W$. circinata var. circinata has not been assigned, $R$. oryzae and $R$. zeae were represented under the anamorphic names of $W$. circinata var. oryzae and W. circinata var. zeae, respectively (5). W. circinata var. circinata forms orange to dark brown, globose sclerotia up to $2 \mathrm{~mm}$ in diameter; $W$. circinata var. oryzae forms orange to salmon, irregularly shaped sclerotia; and $W$. circinata var. zeae forms orange to brown, regularly shaped sclerotia up to 1 $\mathrm{mm}$ in diameter (8).

$R$. oryzae and $R$. zeae were assigned to Waitea anastomosis groups WAG-O and WAG-Z, respectively (13). Hyphal fusion was frequent among isolates belonging to each group, but was rare between the two groups (13). $R$. oryzae has been isolated from wheat, barley $(9,10,12)$, and rice (14), while $R$. zeae has been isolated from corn (17), tall fescue (9), and rice (13). W. circinata var. circinata obtained from agricultural soil in Alaska was pathogenic to barley (8), although no diseases caused by $W$. circinata var. circinata have been named. Both $R$. oryzae and $R$. zeae are causal agents of turfgrass diseases in North America $(3,15)$. Diseases of turfgrass caused by these pathogens occur most frequently during the warm and humid season, at temperatures between 28 and $36^{\circ} \mathrm{C}$, inciting leaf and sheath spot $(3,15)$. The turfgrass disease caused by $R$. oryzae in Japan was reported as a white patch disease on bentgrass in 1990 (19). However, the symptoms of white patch disease (19) are quite similar to the new disease described here. According to Tanpo et al. (19), the initial symptom of white patch disease also appears as an irregular small patch ranging from 10 to $60 \mathrm{~cm}$ in diameter with a light-whitish color. As with the new disease, the symptoms of white patch were found on plant tissues above the soil surface, and healthy leaves remain on several areas of turf inside the rings throughout the season. The symptoms of white 
patch disease can disappear completely at the end of the season. These characteristic symptoms of white patch disease (19) were very similar to symptoms of the new disease.

Other diseases of bentgrass caused by Rhizoctonia spp. are yellow patch and brown patch $(2,3,21)$. Yellow patch, caused by Rhizoctonia cerealis van der Hoeven, a binucleate Rhizoctonia sp. in AG-D, develops yellow to straw-colored patches during cool and warm periods. Brown patch disease, caused by $R$. solani AG 2-2 IIIB, develops during the warm and humid weather in summer. Although the new disease occurs during the same season as brown patch disease, it causes less damage than brown patch and shows a yellowbrown color on creeping bentgrass leaves, while brown patch symptoms include gray-purple or gray-brown lesions on leaves.

The objectives of this study were to compare NP isolates obtained from creeping bentgrass exhibiting symptoms of the new disease with those of $W$. circinata var. circinata, W. circinata var. oryzae, and W. circinata var. zeae based on cultural morphology, hyphal growth rate at different temperatures, pathogenicity, and genetic relatedness using random amplified polymorphic DNA (RAPD) and restriction fragment length polymorphism (RFLP) analysis of ribosomal DNA internal transcribed spacer regions (rDNA-ITS). Additionally, isolates of $R$. oryzae that were reported as the causal agent of white patch disease (RW isolates) (19) on creeping bentgrass were also compared with NP isolates to confirm whether RW isolates were identical with NP isolates.

\section{MATERIALS AND METHODS}

Isolates. Eleven NP isolates were collected from creeping bentgrass exhibiting symptoms of the new disease, and five isolates of $W$. circinata var. circinata, six isolates of W. circinata var. oryzae, and seven isolates of $W$. circinata var. zeae were collected from a range of hosts and geographic areas (Table 1). Three isolates of $R$. oryzae, which were collected from creeping bentgrass exhibiting symptoms of white patch disease (RW isolates) and were provided by Tanpo et al. (19), and one isolate of $R$. solani AG 2-2 IIIB obtained from creeping bentgrass exhibiting symptoms of brown patch disease, were also used in this study.

Colony morphology. A single 5-mm agar disk of each of 30 isolates (11 NP isolates, $3 \mathrm{RW}$ isolates, and 16 isolates of W. circinata) (Table 1) was placed onto the center of a $9-\mathrm{cm}$ petri dish containing 10 $\mathrm{ml}$ of potato dextrose agar (PDA; Becton Dickinson and Company, Sparks, MD). These cultures were grown at $25^{\circ} \mathrm{C}$ in the dark. After 45 days, the color of hyphae and the shape and color of sclerotia were examined. To determine the hyphal diame- ter and number of nuclei per cell, agar disks of each of the 30 isolates were placed onto the center of a 9-cm petri dish containing $10 \mathrm{ml}$ of water agar (WA), grown at $25^{\circ} \mathrm{C}$ for 2 days in the dark, and observed at $\times 400$ using bright field microscopy. The mean hyphal diameter was determined for each isolate by measuring 10 main hyphae. After this measurement, hyphae of each isolate were stained with $3 \% \mathrm{KOH}$ and safranin $\mathrm{O}$, and the number of nuclei were counted in 10 cells selected according to their location in the stain gradient so that nuclei and septa could be distinctly observed (1).

Growth rate. For each isolate, a 5-mm agar disk was placed $1 \mathrm{~cm}$ from the edge of a $9-\mathrm{cm}$ petri dish containing $10 \mathrm{ml}$ of PDA. The hyphal growth rate was determined for 19 isolates (4 NP isolates [NP-1, $-4,-7$, and -8], $3 \mathrm{RW}$ isolates [RW-1 to -3], each of 4 isolates of $W$. circinata var. circinata [Wc-1 to -4], W. circinata var. oryzae [Wo-1 to -4], and W. circinata var. zeae [Wz-1 to -4] [Table 1]) grown on PDA at 15, 20, 22, 25, 28, 30, and $35^{\circ} \mathrm{C}$. Each treatment was replicated three times.
The radius of each colony was measured every $24 \mathrm{~h}$ until the colony reached the edge of the petri dish.

Pathogenicity on creeping bentgrass. Eighteen isolates (4 NP isolates [NP-1, -4, -7, and -8], $3 \mathrm{RW}$ isolates [RW-1 to -3], 3 isolates of $W$. circinata var. circinata $[\mathrm{Wc}-$ 2, -3, and -4], 4 isolates of W. circinata var. oryzae [Wo-1, -3, -4, and -6], and 4 isolates of W. circinata var. zeae [Wz-1 to -4] [Table 1]) were tested for pathogenicity on creeping bentgrass.

Creeping bentgrass was grown for 24 days after seeding prior to inoculation. Seeds were sown by placing $0.14 \mathrm{~g}$ in $14-$ $\mathrm{cm}$-diameter clay pots filled with $1,000 \mathrm{ml}$ of sand, and then covered $2 \mathrm{~mm}$ deep with sand. Each pot was watered twice per day to avoid wilting. Isolates of NP, RW, and three varieties of $W$. circinata were grown on PDA medium for 4 days at $25^{\circ} \mathrm{C}$ in the dark. Agar disks of each isolate were transferred onto $300 \mathrm{ml}$ of soil-bran medium (a mixture of 3 liters of peat moss, 3 liters of wheat bran, 3 liters of rice bran, 6 liters of turfgrass soil, and 1 liter of liquid medium containing $1 \%$ yeast extract and $1 \%$ poly-

Table 1. Isolates from creeping bentgrass with symptoms of new disease (NP), Rhizoctonia oryzae obtained from creeping bentgrass with symptoms of white patch disease, Waitea circinata var. circi$n a t a, W$. circinata var. oryzae, and W. circinata var. zeae used in this study

\begin{tabular}{|c|c|c|c|}
\hline Working no. & Isolate name & Host & Origin \\
\hline \multicolumn{4}{|l|}{ NP isolates } \\
\hline NP-1 & IY-3-2 & Creeping bentgrass & Ehime, Japan \\
\hline NP-2 & MAS-1 & Creeping bentgrass & Ehime, Japan \\
\hline NP-3 & KT-5S-1 & Creeping bentgrass & Kagawa, Japan \\
\hline NP-4 & HHC-13-6 & Creeping bentgrass & Hyogo, Japan \\
\hline NP-5 & HT-1 & Creeping bentgrass & Nagasaki, Japan \\
\hline NP-6 & KT-08-1 & Creeping bentgrass & Kagawa, Japan \\
\hline NP-7 & Ro-1 & Creeping bentgrass & Nagasaki, Japan \\
\hline NP-8 & HTB-A-1 & Creeping bentgrass & Nagasaki, Japan \\
\hline NP-9 & HAT-BG & Creeping bentgrass & Aichi, Japan \\
\hline NP-10 & AMI-BG & Creeping bentgrass & Japan \\
\hline NP-11 & GEN-BG-1 & Creeping bentgrass & Fukuoka, Japan \\
\hline \multicolumn{4}{|c|}{$\mathrm{RW}$ isolates obtained from white patch $(\mathrm{RW})^{\mathrm{z}}$} \\
\hline RW-1 & WP-1 & Creeping bentgrass & Shiga, Japan \\
\hline RW-2 & $\mathrm{R}-2$ & Creeping bentgrass & Kagawa, Japan \\
\hline RW-3 & G-3 & Creeping bentgrass & Kagawa, Japan \\
\hline \multicolumn{4}{|c|}{ W. circinata var. circinata $(\mathrm{Wc})$} \\
\hline Wc-1 & $\mathrm{Z1}$ & Soil & Alaska, USA \\
\hline Wc-2 & Z4 & Soil & Alaska, USA \\
\hline Wc-3 & Z16 & Soil & Alaska, USA \\
\hline Wc-4 & Z41 & Soil & Alaska, USA \\
\hline Wc-5 & $\mathrm{Z} 52$ & Soil & Alaska, USA \\
\hline \multicolumn{4}{|c|}{ W. circinata var. oryzae (Wo) } \\
\hline Wo-1 & Ro36 & Rice & Aichi, Japan \\
\hline Wo-2 & Ro45 & Rice & Okinawa, Japan \\
\hline Wo-3 & RoTTS & Rice & Toyama, Japan \\
\hline Wo-4 & C-301 & Soil & Fukuoka, Japan \\
\hline Wo-5 & C-505 & Soil & Yamagata, Japan \\
\hline Wo-6 & Ro119 & Rice & Japan \\
\hline \multicolumn{4}{|c|}{ W. circinata var. zeae $(\mathrm{Wz})$} \\
\hline Wz-1 & M003 & Soil & Aichi, Japan \\
\hline $\mathrm{Wz}-2$ & M008 & Rice & Aichi, Japan \\
\hline Wz-3 & M009 & Soil & Wakayama, Japan \\
\hline Wz-4 & C-504 & Soil & Ishikawa, Japan \\
\hline Wz-5 & C-522 & Rice & Fukuoka, Japan \\
\hline Wz-6 & $\mathrm{OK}-2 \mathrm{TL}$ & Creeping bentgrass & Kagawa, Japan \\
\hline Wz-7 & BP-Blk & Creeping bentgrass & Kagawa, Japan \\
\hline \multicolumn{4}{|c|}{ R. solani AG 2-2 IIIB } \\
\hline IIIB-1 & $\mathrm{K} 2-10$ & Creeping bentgrass & Gifu, Japan \\
\hline
\end{tabular}

${ }^{\mathrm{z}}$ Provided by Tanpo et al. (19). 
peptone) in 500-ml flasks for 10 days at $25^{\circ} \mathrm{C}$ in the dark. Each culture was homogenized in a mixer and filtered through a 2-mm mesh screen. Twenty milliliters of filtered mycelia were then dispersed over the bentgrass in each pot. The inoculated turf was incubated at $25^{\circ} \mathrm{C}$ with light provided on a $14 / 10 \mathrm{~h}$ day/night cycle in the greenhouse. Each treatment was replicated 10 times. Control plants were treated similarly but without inocula. Disease severity was rated 8 days after inoculation, and was determined by averaging individual scores from 10 leaves per pot, using the following rating scale: $0 \%=$ symptomless; $1 \%=$ small lesions; $5 \%=$ lesions covering $<10 \%$ of the leaf; $30 \%=$ lesions covering 10 to $50 \%$ of the leaf; $70 \%=$ lesions covering $>50 \%$ of a wilted leaf; and $100 \%=$ leaf completely withered. Pathogenicity tests were done twice.

Samples of leaves with lesions were collected 9 days after inoculation. Leaf sheaths $5 \mathrm{~mm}$ long were cut from infected leaves, washed in three changes of distilled water, blotted dry on a sterile paper towel, and placed on WA. Hyphae resembling Rhizoctonia spp. were transferred as hyphal tips onto PDA at $25^{\circ} \mathrm{C}$. The isolation frequency was scored among 20 samples by comparing isolates from leaves with the original isolates used to prepare inocula.

DNA extraction. Mycelia for DNA extraction were cultured in potato dextrose broth (PDB) at $25^{\circ} \mathrm{C}$. After 3 to 4 days, the mycelial mat was harvested by filtration and stored at $-80^{\circ} \mathrm{C}$ until use. Total genomic DNA was extracted as described by Hyakumachi et al. (6).

RAPD analysis. DNA samples from 25 isolates (eight NP isolates [NP-1 to -8], two RW isolates [RW-1 and -2], four isolates of $W$. circinata var. circinata [Wc-1 to -4], five isolates each of $W$. circinata var. oryzae [Wo-1 to -5] and W. circinata var. zeae [Wz-1 to -5], and one isolate of $R$. solani AG 2-2 IIIB [IIIB-1] [Table 1]) were used for RAPD-PCR. PCR amplification reactions were carried out in a $50-\mu \mathrm{l}$ reaction mixture consisting of $200 \mu \mathrm{M}$ each of dATP, dCTP, dGTP, and dTTP, 50 pmol of oligonucleotide primer, $10 \mathrm{mM}$ Tris- $\mathrm{HCl}$ at $\mathrm{pH} 8.3,50 \mathrm{mM} \mathrm{KCl}, 1.5 \mathrm{mM}$ $\mathrm{MgCl}$, and 1.25 units Taq DNA polymerase (Takara Shuzo Co. Ltd., Kyoto, Japan). After quantification of DNA using a DNA/RNA calculator (Amersham Bio- tech, Piscataway, NJ), $50 \mathrm{ng} / \mu \mathrm{l}$ fungal DNA from each of the 25 isolates was used. RAPD analysis of $R$. solani in previous studies could distinguish the inter and intra AG subgroups and the cultural types within subgroups $(4,20,21,22)$. Three useful random primers, R28 (5'-ATGGATCCGC-3'), RC09 (5'-GATAACGCAC-3'), and OPE04 (5'-GTGACATGCC-3'), were selected from the results of these studies. The DNA Thermal Cycler (GeneAmp PCR system 2700; Applied Biosystems, Foster City, CA) was programmed for one cycle of $3 \mathrm{~min}$ at $94^{\circ} \mathrm{C}$, followed by 40 cycles of $1 \mathrm{~min}$ at $94^{\circ} \mathrm{C}, 1 \mathrm{~min}$ at $35^{\circ} \mathrm{C}$, and $2 \mathrm{~min}$ at $72^{\circ} \mathrm{C}$, and one cycle of $7 \mathrm{~min}$ at $72^{\circ} \mathrm{C}$. The RAPD-PCR products were examined by electrophoresis on $1.5 \%$ agarose gel with Tris-acetic EDTA (TAE) buffer. A 100-bp DNA ladder size marker (Invitrogen TECH-LINE, Carlsbad, CA) was also used for each electrophoresis. The agarose gels were stained with ethidium bromide and visualized under UV transillumination.

Amplification with each primer was repeated three times, and only reproducible DNA fragments were scored for each of the 25 isolates. The size of each RAPDPCR product was estimated visually. The

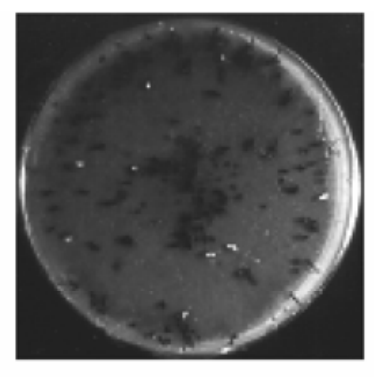

NP isolates

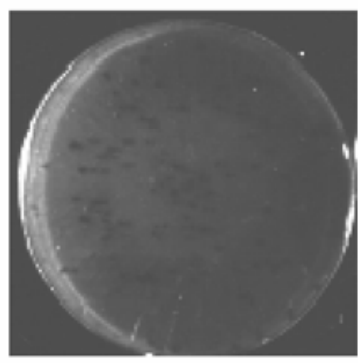

W. circinata var. circinata

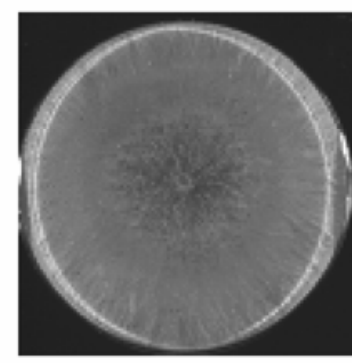

W. circinata var. zeae length of the longest and shortest RAPDPCR products were determined using the linear function made from GROUTH, the software in Microsoft Excel, by defining X as the distance from well to each marker $(\mathrm{mm})$ and $\mathrm{Y}$ as the length of each marker (bp). Reproducibility of DNA fragments by RAPD-PCR was tested three times. Only reproducible products were incorporated into phylogenetic analyses. The presence and absence of products were scored as 1 and 0 , respectively. The data generated from three primers for each isolate were pooled, and a genetic similarity matrix was calculated based on the simple matching coefficient (16). Maximum parsimony trees were produced using the heuristic method of PAUP 4.0b1 (Sinaeur Associates Inc., Sunderland, MA). Clade stability was assessed with 100 bootstrap replications.

RFLP of rDNA-ITS. The amplification reactions of the rDNA-ITS region and its post-treatment were carried out under conditions previously described (6). The entire length of the rDNA-ITS regions were compared among 32 isolates consisting of NP isolates, RW isolates, and W. circinata. The ITS regions of the 32 isolates were

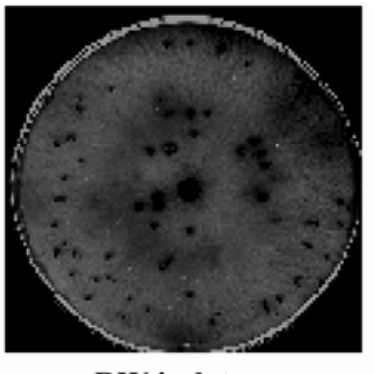

RW isolates

Fig. 1. Cultural morphology of NP isolates, RW isolates, Waitea circinata var. circinata, W. circinata var. oryzae, and W. circinata var. zeae on potato dextrose agar (PDA) after 45 days incubation.

Table 2. Morphological characteristics of NP isolates, isolates of Rhizoctonia oryzae obtained from creeping bentgrass exhibiting the symptoms of white patch disease (RW), Waitea circinata var. circinata, W. circinata var. oryzae, and W. circinata var. zeae

\begin{tabular}{|c|c|c|c|c|c|c|}
\hline \multirow[b]{2}{*}{ Isolates/group } & \multirow[b]{2}{*}{ Nuclei per cell } & \multirow[b]{2}{*}{ Hyphal diameter $(\mu \mathrm{m})$} & \multirow[b]{2}{*}{ Colony color ${ }^{z}$} & \multicolumn{3}{|c|}{ Sclerotia $^{z}$} \\
\hline & & & & Size (mm) & Shape & Color \\
\hline NP & 3 to 9 & 6.3 & Dark brown & $1-3$ & Irregular & Dark \\
\hline RW & 3 to 9 & 6.3 & Dark brown & $1-3$ & Irregular & Dark \\
\hline W. circinata var. circinata & 4 to 9 & 6.4 & Dark brown & $1-3$ & Irregular & Brown \\
\hline W. circinata var. oryzae & 3 to 8 & 6.3 & White to salmon & $1-3$ & Irregular & Salmon \\
\hline W. circinata var. zeae & 3 to 10 & 6.4 & White to orange & $0.5-1$ & Subspheroid & Orange \\
\hline
\end{tabular}

${ }^{\mathrm{z}}$ On potato dextrose agar. 
amplified by PCR and digested separately with enzymes HapII, MboI, and HinfI (Takara Shuzo Co. Ltd.). All digestion reactions contained $1 \mathrm{mM} \mathrm{MgCl} 2,0.1 \mathrm{mM}$ DTT, and 10 units of the appropriate restriction enzyme. The digestion using HapII was carried out in a $12-\mu l$ reaction mixture consisting of the ITS region, template DNA, and $1 \mathrm{mM}$ Tris- $\mathrm{HCl}$ at $\mathrm{pH}$ 7.5. The digestion using HinfI was carried out in a $12-\mu l$ reaction mixture consisting of template, $10 \mathrm{mM} \mathrm{NaCl}$, and $5 \mathrm{mM}$ Tris$\mathrm{HCl}$ at $\mathrm{pH}$ 7.5. The digestion using $\mathrm{MboI}$ was carried out in a $12-\mu \mathrm{l}$ reaction mixture consisting of template, $10 \mathrm{mM} \mathrm{KCl}$, and 2 $\mathrm{mM}$ Tris- $\mathrm{HCl}$ at $\mathrm{pH}$ 8.5. All reaction mixtures were incubated at $37^{\circ} \mathrm{C}$ for $4 \mathrm{~h}$. Furthermore, rDNA-ITS of 19 isolates (11 NP isolates, $3 \mathrm{RW}$ isolates, and 5 isolates of $W$. circinata var. circinata) were digested separately with enzymes BanIII, EcoRI, HaeIII, HindIII, PstI, RsaI, and SalI. The digestions with BanIII, EcoRI, PstI, RsaI, and SalI were done with the same condition as for HinfI. The reaction conditions for HaeIII and HindIII in a $12-\mu$ l reaction mixture consisted of template, $5 \mathrm{mM}$ $\mathrm{NaCl}$, and $1 \mathrm{mM}$ Tris- $\mathrm{HCl}$ at $\mathrm{pH}$ 7.5. The restriction fragments were separated in a $2 \%$ NuSieve (3:1) agarose gel (FMC Bioproducts, Rockl and MN, USA) with TAE buffer. The agarose gels were stained with ethidium bromide and visualized under UV transillumination. Each fragment length was determined using the linear function made from GROUTH, the software in Microsoft Excel, described in the previous section.

\section{RESULTS}

Colony morphology. The colors of young colonies among NP isolates were similar and changed from white or orange to shades of dark brown with increasing age (after 30 days). The sclerotia were irregular in shape and ranged in size from 1 to $3 \mathrm{~mm}$ (Table 2). The color of $W$. circinata var. circinata colonies varied widely, from white or orange to dark brown with increasing age. The sclerotia of this variety were also light to dark brown, and their shape and size were irregular and ranged from 1 to $3 \mathrm{~mm}$ (Table 2). These characteristics were similar to those of RW isolates. The colony colors of $W$. circinata var. oryzae and $W$. circinata var. zeae were white to salmon pink and orange, respectively. The sclerotia of $W$. circinata var. oryzae were salmon pink in color and irregular in shape, and their size ranged from 1 to $3 \mathrm{~mm}$. The sclerotia of $W$. circinata var. zeae were orange in color and globular shaped, and their size was small, ranging up to $1 \mathrm{~mm}$ (Table 2). The mature colonies of NP isolates, RW isolates, and the three varieties of $W$. circinata are shown in Figure 1. The diameter of the hyphae of NP isolates ranged from 4.7 to $7.8 \mu \mathrm{m}$ (Table 2), and the number of nuclei per cell was 3 to 8 (Table 2). These charac- teristics were almost the same as those of RW isolates, W. circinata var. circinata, $W$. circinata var. oryzae, and W. circinata var. zeae.

Growth rate. The mycelial growth rate of NP isolates at 15 to $35^{\circ} \mathrm{C}$ was not significantly different from that of RW isolates and W. circinata var. circinata (Fig. 2 and Table 3). Their mycelial growth rate gradually increased from 15 to $28^{\circ} \mathrm{C}$ and decreased from 28 to $35^{\circ} \mathrm{C}$, and the optimum temperature for growth was $28^{\circ} \mathrm{C}$ (Fig. 2). The mycelial growth rate of $W$. circinata var. oryzae and $W$. circinata var. zeae increased from 15 to $30^{\circ} \mathrm{C}$ and decreased from 30 to $35^{\circ} \mathrm{C}$; the optimum temperature for growth of both varieties was $30^{\circ} \mathrm{C}$ (Fig. 2). NP isolates, RW iso-

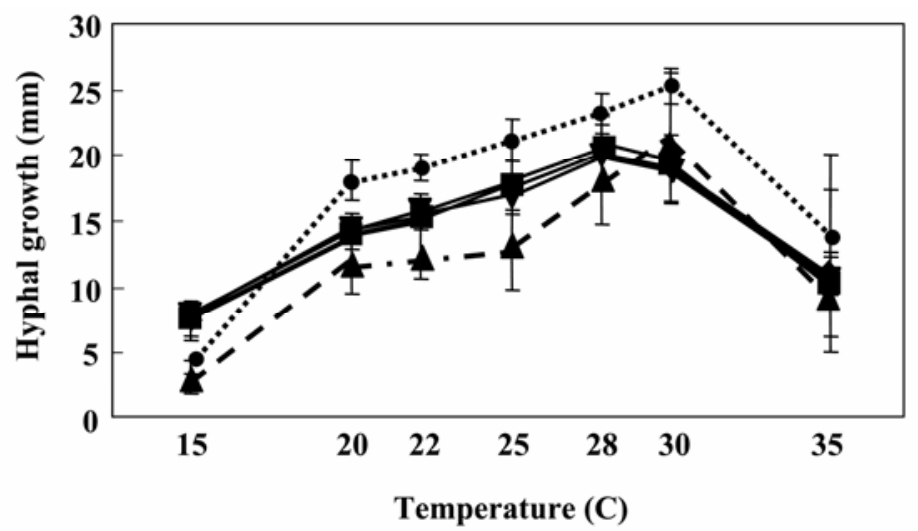

$\multimap-\mathrm{NP}$ isolates $\rightarrow \neg \mathrm{RW}$ isolates $\longrightarrow-$ circinata $-\longleftarrow$ oryzae $\bullet-\cdot$ zeae

Fig. 2. Mycelial growth rate of NP isolates, RW isolates, and three varieties of Waitea circinata. Bars indicate one standard deviation.

Table 3. Hyphal growth $(\mathrm{mm})$ of NP isolates, RW isolates, and Waitea circinata var. circinata, $W$. circinata var. oryzae, and W. circinata var. zeae

\begin{tabular}{llll}
\hline Isolates/group & $\mathbf{1 5}^{\circ} \mathbf{C}$ & $\mathbf{2 8}^{\circ} \mathbf{C}$ & $\mathbf{3 0}^{\circ} \mathbf{C}$ \\
\hline NP isolates & $8.5 \mathrm{c}^{\mathrm{z}}$ & $19.0 \mathrm{a}$ & $18.1 \mathrm{a}$ \\
RW isolates & $8.6 \mathrm{c}$ & $19.8 \mathrm{a}$ & $18.9 \mathrm{a}$ \\
W. circinata var. circinata & $8.8 \mathrm{c}$ & $21.8 \mathrm{ab}$ & $20.4 \mathrm{a}$ \\
W. circinata var. oryzae & $3.3 \mathrm{a}$ & $18.4 \mathrm{a}$ & $23.7 \mathrm{~b}$ \\
W. circinata var. zeae & $4.9 \mathrm{~b}$ & $23.4 \mathrm{~b}$ & $25.3 \mathrm{~b}$ \\
\hline
\end{tabular}

${ }^{z}$ Values followed by the same letter do not differ significantly $(P<0.05)$ according to Duncan's multiple range test.

Table 4. Pathogenicity of NP isolates, RW isolates, Waitea circinata var. circinata, W. circinata var. oryzae, and W. circinata var. zeae

\begin{tabular}{lcc}
\hline Group & $\begin{array}{c}\text { Percent } \\
\text { disease severity }\end{array}$ & $\begin{array}{c}\text { Reisolation } \\
\text { frequency (\%) }\end{array}$ \\
\hline NP & $33.4 \mathrm{c}^{\mathrm{z}}$ & 82.5 \\
RW & $26.0 \mathrm{bc}$ & 83.3 \\
W. circinata var. circinata & $21.1 \mathrm{~b}$ & 80.0 \\
W. circinata var. oryzae & $8.4 \mathrm{a}$ & 83.3 \\
W. circinata var. $z$ zeae & $92.5 \mathrm{~d}$ & 93.7 \\
\hline
\end{tabular}

${ }^{\mathrm{y}}$ Disease severity scale: $0 \%=$ symptomless; $1 \%=$ small lesions; $5 \%=$ lesions covering $<10 \%$ of leaf; $30 \%=$ lesions covering 10 to $50 \%$ of leaf; $70 \%=$ lesions covering $>50 \%$ of a wilted leaf; and $100 \%$ = leaf completely withered. Average disease severity was estimated using NP isolates NP-1, -4, -7, and $-8, W$. circinata var. circinata Wc- $1,-3$, and $-4, W$. circinata var. oryzae Wo- $1,-3,-4$, and -6 , and W. circinata var. zeae $\mathrm{Wz}-2,-3$, and -4 .

${ }^{\mathrm{z}}$ Values followed by the same letter do not differ significantly $(P<0.01)$ according to Duncan's multiple range test. 
bentgrass inoculated with RW isolates. Disease severities on bentgrass inoculated with NP isolates and RW isolates did not differ (Table 4). Disease severity with $W$. circinata var. circinata was slightly less than with NP isolates but similar to that with RW isolates. W. circinata var. oryzae induced yellow and brown lesions, but disease severity was lower and signifiisolates, RW isolates, and W. circinata var. circinata. W. circinata var. zeae isolates induced yellow and orange lesions on cantly different from that induced by NP

bentgrass, and leaves were covered by orange mycelia with many sclerotia. Disease severity incited by $W$. circinata var. zeae isolates was significantly greater than that incited by any other isolates used in this study. Isolates of NP, RW, W. circinata var. circinata, W. circinata var. oryzae, and W. circinata var. zeae were recovered from 80 to $94 \%$ of leaves with lesions (Table 4). The results shown in Table 4 are from one experiment.

RAPD analysis. All three primers amplified DNA from $25 \mathrm{NP}$ isolates, RW
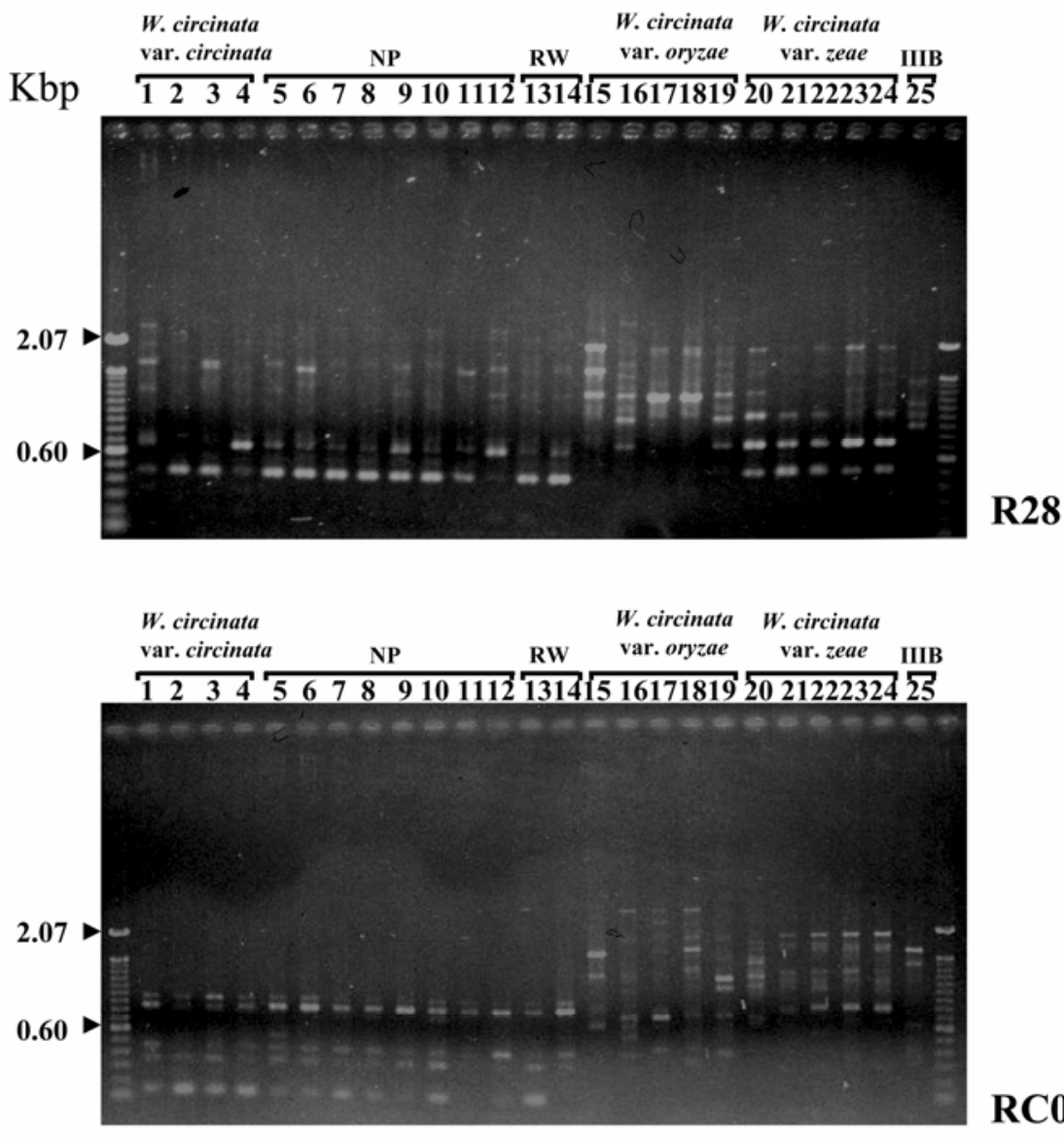

RC09

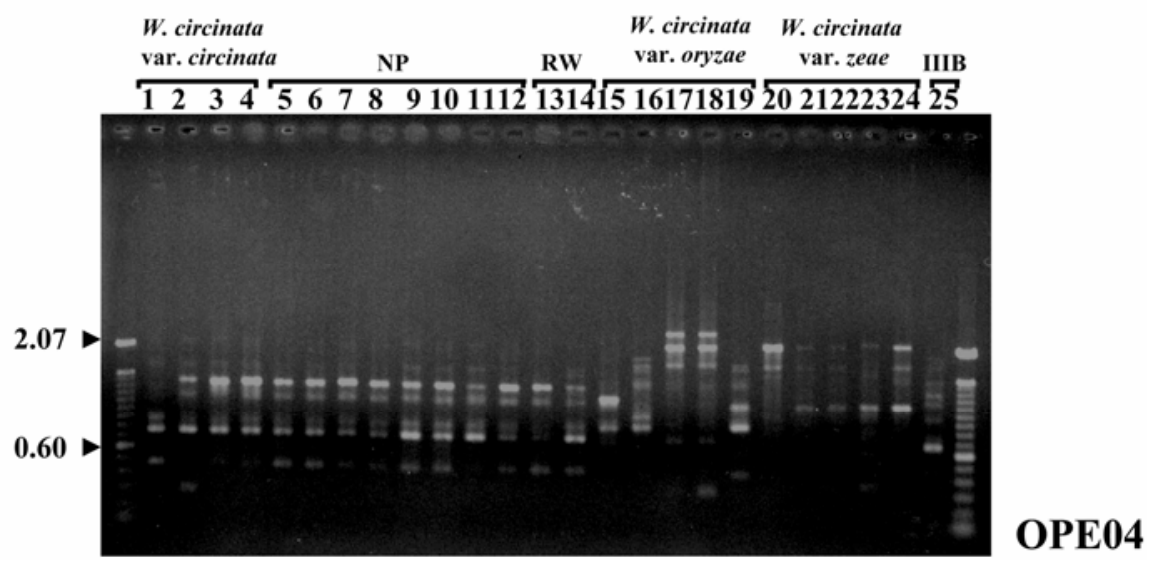

Fig. 3. Random amplified polymorphic DNA (RAPD) banding patterns using primers R28, RC09, and OPE04 of NP isolates, RW isolates, Waitea circinata var. circinata, W. circinata var. oryzae, and W. circinata var. zeae. Lanes 1 to $4, W$. circinata var. circinata; lanes 5 to 12, NP isolates; lanes 13 and 14 , RW isolates; lanes 15 to $19, W$. circinata var. oryzae; lanes 20 to 23, W. circinata var. zeae; lane 25, Rhizoctonia solani AG 2-2 IIIB. Size marker used was 100-bp DNA ladder. isolates, three varieties of $W$. circinata, and $R$. solani AG 2-2 IIIB and gave multiple products in the size range of approximately 0.4 to $4 \mathrm{~kb}$ (Fig. 3). The total number of bands from 25 isolates using primers R28, RC09, and OPE04 was 74. The pattern of bands produced by three primers with NP isolates was similar to the pattern with RW isolates and W. circinata var. circinata and could be distinguished from those of $W$. circinata var. oryzae, W. circinata var. zeae, and $R$. solani AG 2-2 IIIB (Fig. 3). In $W$. circinata var. oryzae and var. zeae, some specific fragments were observed with these three primers for each variety, although their patterns were complex. A single phylogenetic tree was obtained based on the presence or absence of fragments produced with all three primers, and showed obvious variation among NP isolates, RW isolates, the three varieties of $W$. circinata, and $R$. solani AG 2-2 IIIB (Fig. 4). Isolates were clearly separated into three clusters and one outgroup with more than 50 bootstrap values. Isolates of NP, $\mathrm{RW}$, and $W$. circinata var. circinata were clustered together, while isolates of $W$. circinata var. oryzae and $W$. circinata var. zeae made individual clusters. The single isolate of $R$. solani AG 2-2 IIIB was not part of any cluster.

RFLP of rDNA-ITS region. The length of the rDNA-ITS region of all 11 NP isolates, three RW isolates, and five isolates of W. circinata var. circinata was approximately 645 bp (Table 5). The length of the rDNA-ITS region of both $W$. circinata var. oryzae and W. circinata var. zeae isolates was $660 \mathrm{bp}$. Restriction patterns of rDNAITS region by HapII showed two fragments (475 and $170 \mathrm{bp}$ ) for NP isolates, RW isolates, and $W$. circinata var. circinata, but the ITS regions of W. circinata var. oryzae and $W$. circinata var. zeae lacked this restriction site. RFLP analysis of rDNA-ITS with HinfI and MboI could not distinguish among NP isolates, RW isolates, and $W$. circinata var. circinata. RFLP analysis of rDNA-ITS with HinfI and $M b o$ I distinguished between W. circinata var. oryzae and W. circinata var. zeae. Two MboI sites were shared between $W$. circinata var. zeae and W. circinata var. oryzae, and produced three fragments of 250, 245, and 145 bp. W. circinata var. zeae, however, had one additional site within the 245-bp fragment, and this fragment was digested to form 145- and 100bp fragments. Restriction fragments of rDNA-ITS by HinfI showed four fragments (200, 130, 90, and $70 \mathrm{bp}$ ) for $W$. circinata var. oryzae and three fragments (330, 90, and $80 \mathrm{bp})$ for W. circinata var. zeae, respectively. Furthermore, for EcoRI, SalI, and BanIII, the rDNA-ITS region of all NP isolates and W. circinata var. circinata isolates had the same restriction site, and two fragments were produced with both groups of isolates; 320 and $320 \mathrm{bp}$, 470 and $175 \mathrm{bp}$, and 375 and $270 \mathrm{bp}$ for 
these restriction enzymes, respectively. These isolates had no restriction sites for PstI, HindIII, HaeIII, and RsaI.

\section{DISCUSSION}

A new disease on bentgrass caused by a Rhizoctonia sp., typified by NP isolates, was reported in Japan in 1994 (7). It was apparent that these isolates belonged to the Waitea anastomosis group (WAG) because they anastomosed with isolates of WAG-O (W. circinata var. oryzae) and WAG-Z (W. circinata var. zeae) (13). In this study, we clarified that these isolates were different from isolates of $W$. circinata var. oryzae and W. circinata var. zeae, based on cultural characteristics, including color and size of sclerotia, color of mycelia, pigment deposition of media, optimum temperature for growth, and pathogenicity. The colony color of NP isolates was similar to that of RW isolates and some isolates of W. circinata var. circinata, and the mycelial growth rate of NP isolates was the same as that of RW isolates and W. circinata var. circinata. Mycelia of NP isolates, RW isolates, and $W$. circinata var. circinata grew faster at temperatures below $16^{\circ} \mathrm{C}$ than $W$. circinata var. oryzae and W. circinata var. zeae, which corresponds with the report of Leiner and Carling (8). The pathogenicity test also showed that the symptoms observed on creeping bentgrass inoculated by NP isolates were similar to those caused by RW isolates and W. circinata var. circinata. The results of this study indicate that NP isolates causing a new disease of bentgrass and RW isolates causing white patch disease of bentgrass have characteristics similar to $W$. circinata var. circinata.

Based on RAPD-PCR analysis and RFLP of the rDNA-ITS region, NP isolates could be distinguished from $W$. circinata var. oryzae and W. circinata var. zeae, but could not be distinguished from RW isolates and $W$. circinata var. circinata. RAPD primers produced many fragments with NP isolates, RW isolates, three varieties of $R$. circinata, and $R$. solani AG 2-2 IIIB, and there was a high level of variation among the isolates. On the basis of fragment patterns, a phylogenetic tree based on neighbor-joining indicated three clusters and one outgroup. Isolates of W. circinata var. oryzae and W. circinata var. zeae each made an individual cluster, while NP isolates, RW isolates, and $W$. circinata var. circinata made one cluster. Therefore, we can consider that NP isolates, RW isolates, and W. circinata var. circinata belong to the same RAPD group.

The length of the rDNA-ITS regions and restriction enzyme digest patterns with three enzymes could not distinguish isolates of NP, RW, and W. circinata var. circinata. However, RFLP analysis with HapII of the rDNA-ITS region was useful to separate isolates of NP, RW, and $W$. circinata var. circinata from W. circinata

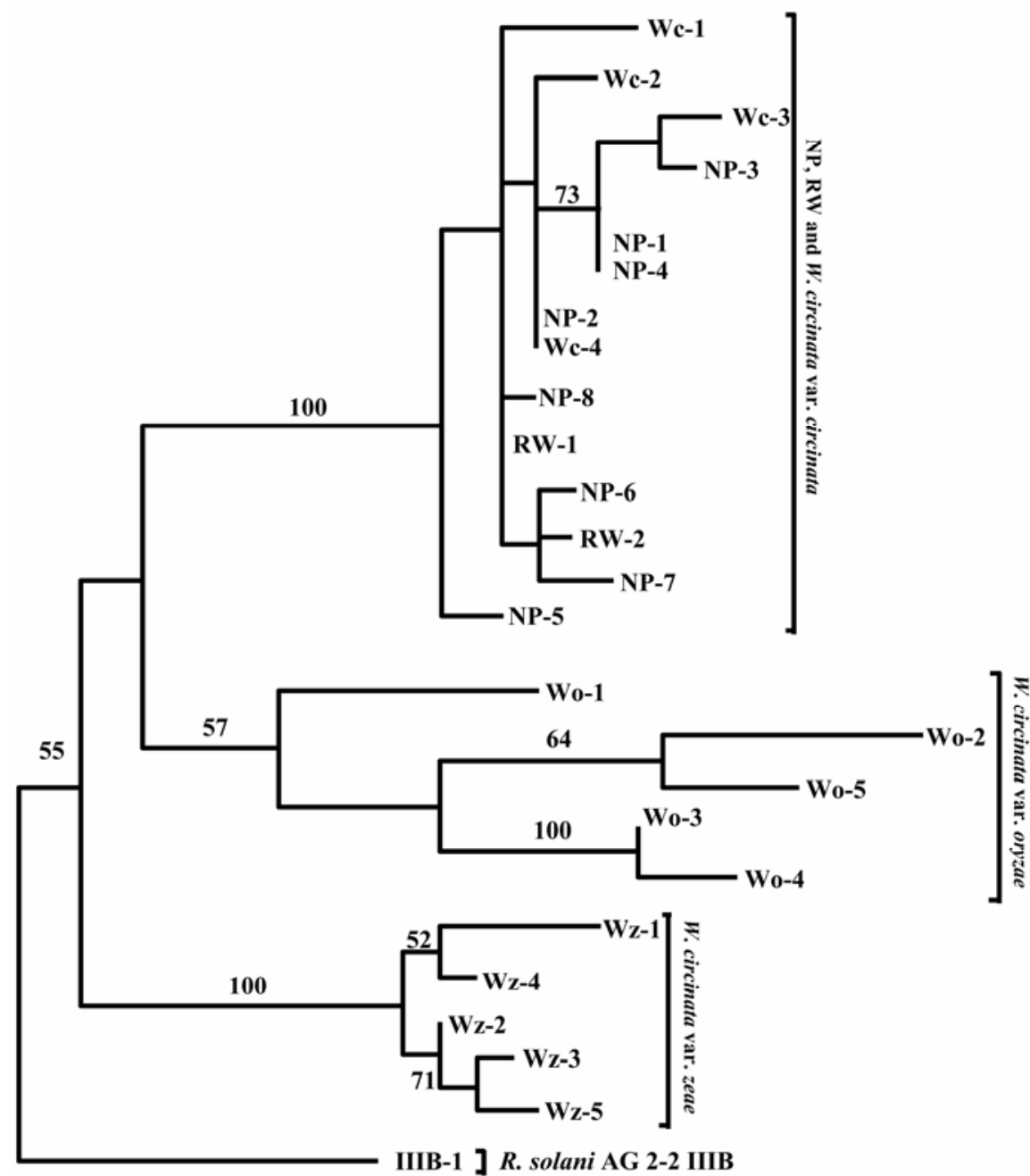

- 5 changes

Fig. 4. Phylogenic tree based on random amplified polymorphic DNA-polymerase chain reaction (RAPD-PCR) banding patterns of Waitea circinata isolates. An isolate of Rhizoctonia solani AG 22 I1IB was used as an outgroup to root the tree. Tree length was 532 steps. Edges of length and bootstrap replication frequencies above $50 \%$ are indicated on branches. For isolate identification see Table 1.

Table 5. Estimated restriction fragment lengths (in base pairs) produced by three restriction enzymes in the ribosomal DNA internal transcribed spacer region (including 5.8S rDNA) for NP isolates, RW isolates, and three varieties of Waitea circinata

\begin{tabular}{lccccc}
\hline & \multicolumn{5}{c}{ Varieties of W. circinata } \\
\cline { 2 - 6 } Restriction site & NPy $^{\mathbf{y}}$ & RW & circinata & oryzae & zeae \\
\hline HapII & $\ldots$ & $\ldots$ & $\ldots$ & 660 & 660 \\
& 475 & 475 & 475 & $\ldots$ & $\ldots$ \\
MboI & 170 & 170 & 170 & $\ldots$ & $\ldots$ \\
& 245 & 245 & 245 & 250 & 250 \\
& 230 & 230 & 230 & $\ldots$ & 245 \\
HinfI & 145 & 145 & 145 & 145 & 145 \\
& $\ldots$ & $\ldots$ & $\ldots$ & 100 & 100 \\
& 330 & 330 & 330 & $\ldots$ & 330 \\
& $\ldots$ & $\ldots$ & $\ldots$ & 200 & $\ldots$ \\
Total & $\ldots$ & $\ldots$ & $\ldots$ & 130 & $\ldots$ \\
\hline
\end{tabular}

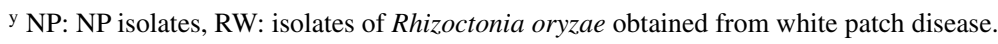

${ }^{\mathrm{z}}$ Restriction fragments are missing. 
var. oryzae and W. circinata var. zeae. Furthermore, restriction patterns by $\mathrm{MboI}$ and HinfI clearly distinguished W. circinata var. oryzae from $W$. circinata var. zeae. The restriction sites of rDNA-ITS regions in this study did not corresponded with previously reported sequences of $R$. oryzae (10). Isolates of $W$. circinata var. oryzae had a high level of variation based on RAPD analysis and a different response of hyphal growth to high temperatures $(8,12)$. There might be several subgroups in this variety. The results obtained from DNA analyses, showing that NP isolates could not be distinguished from RW isolates and $W$. circinata var. circinata but could be distinguished from $W$. circinata var. oryzae and $W$. circinata var. zeae, were consistent with their cultural characteristics.

Tanpo et al. (19) reported that $R$. oryzae (RW isolates) was the causal agent of white patch disease on bentgrass in Japan. The disease symptoms caused by $R$. oryzae were very similar to the new disease caused by NP isolates in this report except for whitish color. In this study, we used isolates of Tanpo et al. (19), which showed almost the same cultural characteristics and pathogenicity as NP isolates and $W$. circinata var. circinata but not W. circinata var. oryzae. Moreover, RW isolates were placed into the same groups as W. circinata var. circinata based on RAPD-PCR and RFLP analysis of rDNA-ITS region. Therefore, the identification of RW isolates as $R$. oryzae proposed by Tanpo et al. (19) should be reconsidered as W. circinata var. circinata.

Based on the results of this study, we recognized that the NP isolates causing the new disease and the RW isolates, which had been considered to be $R$. oryzae, cause of white patch disease, both belong to $W$. circinata var. circinata. However, the name "white patch" cannot be used for this turf disease, because the same name has already been used by another fungal disease for tall fescue (Festuca arundinacea Schreb) caused by Melanotus phillipsii Singer (18). As Tanpo et al. (19) noted, the affected turf develops rings and shows a clear patch with a brownish color including yellow or white. From these symptoms, we propose that the name of the new disease is "brown ring patch".

\section{ACKNOWLEDGMENTS}

We thank Kimiharu Inagaki and Donald E. Carling for providing isolates and Brenda $\mathrm{K}$. Kranz for the technical review of this manuscript.

\section{LITERATURE CITED}

1. Bandoni, R. J. 1979. Safranin O as a rapid nuclear stain for fungi. Mycologia 71:873-874.

2. Burpee, L. 1980. Rhizoctonia cerealis causes yellow patch of turfgrass. Plant Dis. 64:11141116.

3. Burpee, L., and Martin, B. 1992. Biology of Rhizoctonia species associated with turfgrasses. Plant Dis. 76:112-117.

4. Duncan, S., Barton, J. E., and O'Brien, P. A. 1993. Analysis of variation in isolates of Rhizoctonia solani by random amplified polymorphic DNA assay. Mycol. Res. 97:10751082 .

5. Gunnell, P. S. 1986. Characterization of the teleomorphs of Rhizoctonia oryzae-sativae, Rhizoctonia oryzae, and Rhizoctonia zeae, and the effect of cultural practices on aggregate sheath spot of rice, caused by $R$. oryzaesativae. Ph.D. thesis. University of California, Davis.

6. Hyakumachi, M., Mushika, T., Ogiso, Y., Toda, T., Kageyama, K., and Tsuge, T. 1998. Characterization of a new cultural type (LP) of Rhizoctonia solani AG2-2 isolated from warmseason turfgrasses, and its genetic differentiation from other cultural types. Plant Pathol. 47:1-9.

7. Kitabayashi, H., Tanaka, A., and Tani, T. 1994. New disease of bentgrass caused by Rhizoctonia sp. J. Jpn. Soc. Turf. Sci. 23:74 (Abstr. in Japanese).

8. Leiner, R.H., and Carling, D.E. 1994. Characterization of Waitea circinata (Rhizoctonia) isolated from agricultural soils in Alaska. Plant Dis. 78:385-388.

9. Martin, S. B., Jr., and Lucas, L. T. 1983. Pathogenicity of Rhizoctonia zeae on tall fescue and other turfgrasses. Plant Dis 67:676-678.

10. Mazzola, M., Wong, T. O., and Cook, R. J. 1996. Virulence of Rhizoctonia oryzae and $R$. solani AG-8 on wheat and detection of $R$. oryzae in plant tissue by PCR. Phytopathology 86:354-360.

11. Mushika, T., Tanaka, A., Kageyama, K., Tani, T., and Hyakumachi, M. 1995. Identification of the causal pathogen, Rhizoctonia sp., of new disease of bentgrass. Ann. Phytopathol. Soc. Jpn. 61:634 (Abstr. in Japanese).

12. Ogoshi, A., Cook, R. J., and Bassett, E. N. 1990. Rhizoctonia species and anastomosis groups causing root rot of wheat and barley in the Pacific Northwest. Phytopathology 80:784788.

13. Oniki, M, Ogoshi, A., Araki, T., Sakai, R., and Tanaka, S. 1985. The perfect state of Rhizoctonia oryzae and $R$. zeae and anastomosis groups of Waitea circinata. Trans. Mycol. Soc. Jpn. 26:189-198.

14. Ryker, T. C., and Gooch, F. S. 1938. Rhizoctonia sheath spot of rice. Phytopathology 28:233-246.

15. Smiley, R. W., Dernoeden P. H., and Clarke, B. B. 1992. Compendium of Turfgrass Diseases. American Phytopathological Society, St. Paul, MN.

16. Sneath, P. H. A., and Sokal, R. R. 1973. Numerical Taxonomy: The Principles and Practice of Numerical Classification. W. H. Freeman and Co., San Francisco.

17. Sumner, D. R., and Bell, D. K. 1982. Root diseases induced in corn by Rhizoctonia solan and Rhizoctonia zeae. Phytopathology 72:8691

18. Tani, T., and Beard, J. B. 1996. Color Atlas of Turfgrass Diseases. Ann Arbor Press, Chelsea, MI.

19. Tanpo, H., Tsukamoto, T., Tani, T., and Ogoshi, A. 1990. A new disease found in Japan on bentgrass turf caused by Rhizoctonia oryzae. J. Jpn. Soc. Turf. Sci. 18:125-132.

20. Toda, T., Hyakumachi, M., and Arora, D. K. 1999. Genetic relatedness among and within different Rhizoctonia solani anastomosis groups as assessed by RAPD, ERIC and REPPCR. Microbiol. Res. 154:247-258.

21. Toda, T., Hyakumachi, M., Suga, H., Kageyama, K., Tanaka, A., and Tani, T. 1999. Differentiation of Rhizoctonia AG-D isolates from turfgrass into subgroups I and II based on rDNA and RAPD analysis. Eur. J. Plant Pathol. 105:835-846.

22. Yang, H. A., Sivasithamparam, K., Barton, J. E., and O'Brien, P. A. 1995. Characterization of cereal bare patch isolates of Rhizoctonia solani by random amplified polymorphic DNA analysis. Plant Pathol. 44:811-818. 